\title{
DEMAND FOR FOOD COMMODITIES IN TULUNGAGUNG REGENCY
}

\author{
Nur'aini 'Afiifah H., Ratya Anindita, Condro Puspo Nugroho \\ Department of Social Economics, Faculty of Agriculture, Brawijaya University \\ *Corresponding author: afiifahnuraini@gmail.com
}

\begin{abstract}
Food is a basic need that must be fulfilled by every citizen / community and is the right of every resident to fulfill his food needs. So, it is natural that many countries whose governments give considerable attention to food-related problems both in terms of demand and supply. Research on demand for food commodities in Tulungagung Regency uses data from SUSENAS (National Socio-Economic Survey) in 2018 obtained from the Indonesian Central Bureau of Statistics. The model used in this study is the AIDS (Almost Ideal Demand System) model with the SUR (Seemingly Unrelated Regression) method. The results showed that the factors that influenced the demand for food commodities were rice prices, corn prices, soybean prices, mungbean prices, peanut prices for cassava prices, sweet potato prices, and total household expenditure. Price elasticity is elastic for food commodities (rice, corn, green beans, peanuts, cassava and sweet potatoes). Cross elasticity has a substitution relationship in each commodity and is also complementary in each commodity. Expenditure elasticity shows that all food commodities are normal goods.
\end{abstract}

Keywords: Food Demand, Almost Ideal Demand System, Price Elasticity, Cross Elasticity, Expenditure Elasticity.

http://dx.doi.org/10.21776/ub.agrise.2020.020.3.6

Received 22 August 2019

Accepted 21 April 2020

Available online 29 July 2020

\section{INTRODUCTION}

Food is a basic need that must be fulfilled by every resident/community and is the right of every resident to fulfill his food needs, this is in accordance with Law No. 18 of 2012 concerning food. So, it is natural that many countries whose governments pay considerable attention to food-related problems both in terms of demand and supply.

Based on BPS data in 2016, the development of harvested area and production of food commodities in Indonesia for the 2012-2016 period has increased by an average of 2,67\% per year with increasing production with an average of 3,81\% per year. So that in the future Indonesia is expected to increase food production because it is predicted that Indonesia's population will continue to grow. The increase in population will be accompanied by an increase in both food and non-food consumption.

Fluctuating consumption of food commodities at the household level in Indonesia has increased and decreased every year, the increase and decrease is due to the demand for food commodities, prices, an increase in population, and improvement in living standards (Pusdatin Ministry of Agriculture, 2016). The consumption of rice at the household level tends to decrease by $1,14 \%$ per year, consumption of peanuts during the period 2006-2015 has a downward trend with an average decline of $0,31 \mathrm{~kg}$ / capita / year, consumption of cassava in 2016-2020 estimated to experience an average decline of $11.44 \%$ or $2,82 \mathrm{~kg} /$ capita / year, sweet potato consumption is expected to increase in 2016-2020 with an average increase of 4,88 or $2,90 \mathrm{~kg} /$ capita / year .

Guaranteed consumption of protein and calories in food commodities for the community as well as quality and affordable prices is a plan to be achieved in the preparation of national food and nutrition policies (Bappenas, 2011). Therefore, it is necessary to analyze the factors that influence the demand for food commodities in Tulungagung Regency. 


\section{RESEARCH METHODS}

\section{Almost Ideal Demand System (AIDS)}

The AIDS (Almost Ideal Demand System) model is one of the most frequently used models in demand analysis that was first introduced by Deaton and Meulbeur in 1980. The AIDS model has a share of budget which is a linear function of the logarithm of total budget (income). This model is a demand model derived from linear indirect utility functions also in the logarithm of total revenue. The use of the AIDS model in calculating demand has the advantages of being flexible, easily estimated, and having a functional form that is consistent with the household budget (Anindita, 2008).

The beginning of the AIDS model is in the form of expenditure functions that are spent to achieve $U$ utility satisfaction when the price is $p$, these functions are:

$$
\begin{aligned}
\text { Ln e }(\mathrm{u}, \mathrm{p})= & \alpha_{0}+\Sigma_{\mathrm{k}} \alpha_{0} \ln p_{k}+1 / 2 \Sigma_{\mathrm{k}} \Sigma_{\mathrm{i}} \gamma_{i j} \ln p_{k} \ln \\
& p_{j}+\mathrm{u} \beta_{0} \Pi_{k} \mathrm{pk}^{\beta \mathrm{k}} \ldots \ldots . .(1)
\end{aligned}
$$

With $\alpha, \gamma$, and $\beta$ is a parameter. Then the equation is differentiated against pi so that the result:

$$
\frac{\partial \log e(u, p)}{\partial \log p i}=\frac{\partial e(u, p) \cdot p i}{\partial p i, e(u, p)}=\frac{p i C i}{e(u, p)}=\operatorname{Si} \ldots \ldots .(2)
$$

Where Si is part of item I in total expenditure e (p, u), because:

$$
\begin{aligned}
\frac{\partial \log e(u, p)}{\partial \log p i}= & \alpha_{i}+\Sigma_{\mathrm{k}} \lambda \mathrm{ij} \log \mathrm{pj}+\beta_{0} \beta_{i u} \Pi_{k} \mathrm{pk}^{\beta \mathrm{k}} . \\
& \gamma \mathrm{ij}=1 / 2\left(\gamma^{*} \mathrm{ij}+\gamma^{*} \mathrm{ji}\right) \ldots \ldots(4)
\end{aligned}
$$

the combination will produce a hicksian demand (demand in terms of utility not income), namely:

$$
\mathrm{Ci}=\frac{e(u, p)}{p i}\left(\alpha \mathrm{i}+\sum_{\mathrm{k}} \lambda \mathrm{ij} \log \mathrm{pj}+\beta_{0} \beta_{\mathrm{i}} \mathrm{u} \Pi_{\mathrm{k}} \mathrm{pk}^{\beta \mathrm{k}} .\right.
$$

Then the inversion of the expenditure function to obtain $\mathrm{u}$ is:

$$
\begin{gathered}
\ln \gamma=\alpha_{0}+\sum \mathrm{k} \alpha_{\mathrm{k}} \ln \mathrm{p}_{\mathrm{k}}+1 / 2 \sum_{\mathrm{k}} \sum_{\mathrm{j}} \gamma^{*}{ }_{\mathrm{ij}} \ln \mathrm{p}_{\mathrm{k}} \ln \mathrm{p}_{\mathrm{j}}+\mathrm{u} \\
\beta_{0} \beta_{\mathrm{i}} \Pi_{\mathrm{k}} \mathrm{pk}^{\beta \mathrm{k}} \ldots(6) \\
\mathrm{u}=\frac{\log y}{\beta 0 \Pi \mathrm{k} \mathrm{pk} \beta \mathrm{k}}-\frac{\alpha 0+\sum \mathrm{k} \alpha \mathrm{k} \ln p k+\frac{1}{2} \sum \mathrm{k} \sum \mathrm{j} \gamma * \mathrm{j} \ln p k \ln p j}{\beta 0 \Pi \mathrm{k} p \mathrm{k} \beta \mathrm{k}} \ldots(7)
\end{gathered}
$$

Then substitute $\mathrm{u}$ into the equation of the expenditure section, it will get the share expenditure function written as a function of income and all prices, the equation is:

$$
\begin{aligned}
& \mathrm{Si}=\alpha \mathrm{i}+\sum_{\mathrm{i}} \lambda \mathrm{ij} \ln \mathrm{pj}+\beta_{0} \beta_{\mathrm{i}} \Pi_{\mathrm{k}} \mathrm{pk}^{\beta \mathrm{k}}\left[\frac{\ln y}{\beta 0 \Pi \mathrm{k} \mathrm{pk}^{\beta \mathrm{k}}}-\right. \\
& \left.\frac{{ }^{\alpha 0+} \sum \mathrm{k} \alpha \mathrm{k} \ln p k+\frac{1}{2} \sum \mathrm{k} \sum \mathrm{j} \gamma * \mathrm{ij} \ln p k \ln p j}{\beta 0 \Pi \mathrm{k} \mathrm{pk}^{\beta \mathrm{k}}}\right] .
\end{aligned}
$$

The equation is simplified to be:

$$
\mathrm{Si}=\alpha \mathrm{i}+\sum_{\mathrm{k}} \lambda \mathrm{ij} \ln \mathrm{pj}+\beta_{\mathrm{i}}+\ln \frac{y}{p} \ldots
$$

Or it can be written as follows:

$$
\mathrm{Wi}=\alpha \mathrm{i} \sum_{j=1}^{n} \gamma i j \log \mathrm{pj}+\beta_{\mathrm{i}} \log (\mathrm{x} / \mathrm{p}) \ldots
$$

Where:

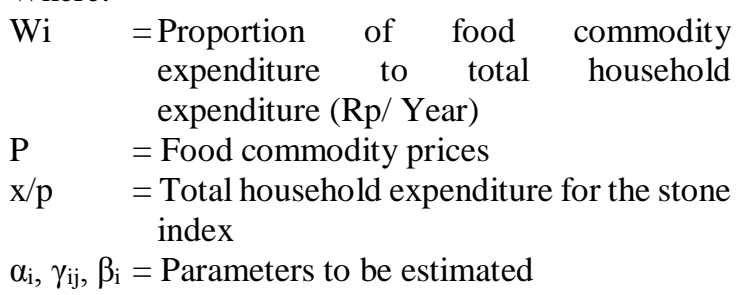

The stone index used is:

Information:

$$
\mathrm{p}=\sum \mathrm{wi} \log P
$$

$\mathrm{p} \quad=$ Stone index

$\mathrm{Wi}=$ Proportion of food commodity expenditure to total household expenditure ( $\mathrm{Rp} / \mathrm{Y}$ ear)

$\mathrm{P} \quad=$ Food commodity prices $(\mathrm{Rp} / \mathrm{Kg})$

The assumptions of the linear approximation of the AIDS model are:

$$
\begin{array}{ll}
\sum_{i} a_{j}=1, \sum_{i} c_{i j}=0, \sum_{i} b_{i}=0 & \text { aditivity .....(12) } \\
\sum_{i} c_{i j}=0 & \text { homogeneity....(13) } \\
\mathrm{Cij}=\mathrm{cij} & \text { simetry ......(14) }
\end{array}
$$

\section{Marshallian and Hicksian elasticity}

1. Elastisitas Marshallian

$$
\begin{aligned}
& \text { a. Price elasticity } \\
& e_{i i}=1+\left(\frac{\gamma_{i j}}{w_{i}}\right)-\beta_{i}
\end{aligned}
$$

b. Cross elasticity

$$
e_{i i}=\left(\frac{\gamma_{i j}}{w_{i}}\right)-\beta_{i}\left(\frac{w_{j}}{w_{i}}\right)
$$

c. Expenditure elasticity

$$
\eta_{i}=1+\frac{\beta_{i}}{w_{i}}
$$

2. Hicksian elasticity

Elasticity that depends on the price effect, with the formula:

$$
e_{i j}=\varepsilon_{i j}+\eta_{i} \times w_{i}
$$

\section{RESULTS AND DISCUSSION}

\section{Results of Analysis of Food Commodity Demand}

Demand for food commodities in 2018 is estimated using the AIDS (Almost Ideal Demand System) model and also uses restriction tests namely homogeneity, symmetry, and adding-up (Anindita, 2017). The results of the restriction test can be seen in table 1 . 
Table 1. Test Results for Restriction Test of Demand for Food Commodity

\begin{tabular}{lcc}
\hline \multicolumn{1}{c}{ Restriction } & $\begin{array}{c}\text { Wald Test } \\
\text { Statistic }\end{array}$ & p-value \\
\hline Homogeneity & 0,80 & 0,304 \\
Symetry & 0,48 & 0,226 \\
\hline
\end{tabular}

Source: Secondary Data Processed, 2019

The results of the tests above show that the demand model for food commodities in 2018 meets the assumption of restriction test.

The

parameter of the demand function of food commodities in Tuluungagung Regency resulting from SUR (Seemingly Unrelated Regression) regression can be seen in table 2 . The $F$ test is carried out to determine the effect of independent variables on the dependent variable simultaneously. The results of the $\mathrm{F}$ test show that the equations in the model are significant at the level of $30 \%$, which means that all independent variables simultaneously have a significant effect on the dependent variable.

The coefficient of determination $\mathrm{R} 2$ in the demand model of food commodities is ranging from $0,33-0,82$ or $33,00 \%-82,00 \%$ can explain the dependent variable and the rest is influenced by other variables outside the model. So that the consumer's decision to consume food commodities is greatly influenced by food commodity prices, other food commodity prices, and income levels.

Table 2. Results of Regression Analysis of Demand for Food Commodity in Tulungagung Regency

\begin{tabular}{|c|c|c|c|c|c|c|}
\hline \multirow[b]{2}{*}{ Label } & \multicolumn{6}{|c|}{ Parameter Estimasi } \\
\hline & Rice & Corn & Green beans & Peanuts & Cassava & $\begin{array}{l}\text { Sweet } \\
\text { potato }\end{array}$ \\
\hline Intercept & 8,19 & 2,86 & 0,13 & 1,91 & $-0,58$ & 0,73 \\
\hline Rice & $-0,21 *$ & $-0,24 * * *$ & $0,10 * *$ & $-0,26 * * *$ & $0,06 * *$ & $0,05 * * *$ \\
\hline Corn & $-0,18 * * *$ & $-0,37 * * *$ & $-0,04 * * *$ & $-0,27 * * *$ & $0,08 * *$ & $-0,03 * * *$ \\
\hline Soy & $-0,89 * * *$ & $-0,29 * * *$ & $-0,07 * * *$ & $0,12 *$ & $0,06 * *$ & $-0,38 * * *$ \\
\hline Green beans & $-0,19 * * *$ & 0,36 & $0,05 * * *$ & $-0,29 * * *$ & $-0,04 * * *$ & $0,00003 * * *$ \\
\hline Peanuts & $-0,42 * * *$ & $-0,13 * * *$ & $0,003 * * *$ & 0,35 & $0,05 * * *$ & $-0,17 * * *$ \\
\hline Cassava & $0,01 * * *$ & $0,06 * *$ & $-0,05 * * *$ & $-0,08 * * *$ & $-0,03 * * *$ & $-0,01 * * *$ \\
\hline Sweet potato & $-0,19 * * *$ & $-0,08 * * *$ & $-0,02 * * *$ & $-0,02 * * *$ & $-0,001 * * *$ & $0,06 * *$ \\
\hline $\mathrm{X} / \mathrm{P}$ & $-0,32 * * *$ & $0,04 * * *$ & $-0,01 * * *$ & $-0,05 * * *$ & $-0,02 * * *$ & $-0,02 * * *$ \\
\hline
\end{tabular}

Source: Secondary Data Processed, 2019

Variables suspected of spending on food commodities that have a significance value of less than $20 \%$ can indicate that consumer decision making to consume food commodities is strongly influenced by income. So that in the positive sign model shows that if there is an increase in people's income, the consumption of food commodities will also increase. Conversely, if the equation shows a negative sign, the proportion of demand for food commodities will decrease along with the decrease in income level.

In general, the variables of food commodity prices and total household expenditure variables have a significant influence on the factors that affect the demand for food commodities. Based on Table 2 , it can be seen that the variable price of rice is significant up to the level of $0,20(20 \%)$. This shows that the effect of rice commodity prices on demand is real. The rice variable to the price of rice is $-0,21$ and is significant at 0,20 or $20 \%$. The effect of own negative prices indicates that if prices rise, the demand for rice commodities will fall, and will have an impact on other food commodities. Thus if the price of rice increases by 1 rupiah, the chance of consuming rice will decrease by 0,21 . Variables of rice to the price of corn, soybeans, green beans, peanuts, and sweet potatoes, each worth $-0,18$; 0,$89 ;-0,19 ;-0,42$; and $-0,19$ and significant at 0,05 (5\%). The effect of cross prices which is negative shows that the goods are complementary goods, so that the commodity of rice to corn, soybeans, green beans, peanuts, and sweet potatoes has a complementary relationship. The rice variable on cassava prices is 0,01 and significant at $0,05(5 \%)$. The effect of positive price cross shows that the goods are substitute goods, so that the commodity of rice and cassava have a substitution relationship.

Corn commodity also occurs to the price of corn worth $-0,37$ and significant at $0,05(5 \%)$. The effect of own negative prices indicates that if prices rise, the demand for these commodities will fall, and will have an impact on other food commodities. Thus if the price of corn increases by 1 rupiah, the demand for corn will decrease by 0,37 . Corn variables on the price of rice, soybeans, peanuts, and sweet potatoes, 
each worth $-0,24 ;-0,29 ;-0,13$, and $-0,08$ and are significant at $0,05(5 \%)$. The influence of negative cross prices shows that the goods are complementary goods, so that the commodity of corn to rice, soybeans, peanuts, and sweet potatoes has a complementary relationship. Variable corn on cassava prices is 0,06 and significant at $0,10(10 \%)$. The effect of positive price cross shows that the goods are substitute goods, so that the commodity of corn and cassava have a substitution relationship.

Also occurred in the commodity green beans against the price of green beans valued at 0,05 and significant at $0,05(5 \%)$. The effect of own positive price indicates that if the price rises, the demand for these commodities will rise, and will have an impact on other food commodities. Thus if the price of green beans increases by 1 rupiah, the demand for green beans will increase by 0,05 . Green bean variable to the price of rice and peanuts worth 0,10 and 0,003 and significant at $0,10(10 \%)$. The effect of positive price cross shows that the goods are substitute goods, so that the commodity between green beans and rice and peanuts has a substitution relationship. Variables of green beans on the price of corn, soybeans, cassava, and sweet potatoes are worth $-0,04$ each; $-0,07 ;-0,05$; and $-0,02$ and significant at $0,05(5 \%)$. The influence of negative cross-prices shows that the goods are complementary goods, so that the commodity of green beans against corn, soybeans, cassava, and sweet potatoes has a complementary relationship.

Also occurred in the commodity peanut to the price of rice, corn, green beans, cassava, and sweet potatoes each valued $-0,26 ;-0,27 ;-0,29 ;-0,08$; and $-0,02$ and significant at $0,05(5 \%)$. The influence of cross prices which has a negative value indicates that the goods are complementary goods, so that the commodity between peanuts with rice, corn, green beans, cassava, and sweet potatoes has a complementary relationship. The variable of peanut to soybean prices is 0,12 and significant at 0,05 $(5 \%)$. The effect of positive price cross shows that the goods are substitute goods, so that the commodity between peanuts and soybean has a substitution relationship.

Also occurred in the commodity cassava to the price of cassava valued at $-0,03$ and significant at $0,05(5 \%)$. The effect of own negative prices indicates that if prices rise, the demand for these commodities will fall, and will have an impact on other food commodities. Therefore, if the price of cassava increases by 1 rupiah, the demand for cassava will decrease by 0,03 . Variable cassava on the price of rice, corn, soybeans, and peanuts each valued at 0,$06 ; 0,08 ; 0,06$; and 0,05 significant at $0,10(10 \%)$. The effect of positive price cross shows that the goods are substitute goods, so that the commodity of cassava and rice has a substitution relationship. Variable of cassava for the price of green beans and sweet potatoes is $-0,04$ and $-0,001$ and significant at $0,05(5 \%)$. The influence of cross prices which has a negative value indicates that the goods are complementary goods, so that the commodity of cassava with green beans and sweet potatoes has a complementary relationship.

Sweet potato also happened to the price of sweet potato valued at 0,06 and significant at $0,10(10 \%)$. The effect of own positive price indicates that if the price rises, the demand for these commodities will rise, and will have an impact on other food commodities. Thus if the price of sweet potatoes increases by 1 rupiah, the demand for sweet potatoes will increase by 0,06 . Variables of sweet potato to the price of rice, and mung beans are respectively 0,05 and 0,003 significant at $0,10(10 \%)$. The effect of positive price cross shows that the goods are substitute goods, so that between sweet potato commodity with rice and green beans have a substitution relationship. Variables of sweet potato to the price of corn, soybeans, peanuts, and cassava are worth respectively $-0,03 ;-0,38 ;-0,17$; and $-0,01$ significant at $0,05(5 \%)$. The influence of cross prices which has a negative value indicates that the goods are complementary goods, so that between sweet potato commodities with corn, soybeans, peanuts, and cassava have a complementary relationship.

The total household expenditure variable for rice, green peas, peanuts, cassava, and sweet potatoes each has a value of $-0,32 ;-0,01 ;-0,05$; 0,02 ; and $-0,02$ and significant at $0,05(5 \%)$. The effect of total negative expenditure on households shows that if total household expenditure increases, the consumption of rice, green peas, peanuts, cassava, and sweet potatoes will decrease. While the total household expenditure variable on corn commodity is worth 0.04 and significant at 0,05 $(5 \%)$. The effect of total positive household expenditure shows that if total household expenditure increases, consumption of corn commodity will increase.

\section{Food Commodity Demand Elasticity}

Measurement of variable change responses (elasticity) includes price elasticity (response to changes in demand for a commodity due to changes in own prices), cross elasticity (response to changes in demand for a commodity due to changes in prices of other commodities), income elasticity (response to changes in the demand for a commodity due to changes in income level )

Marshallian price elasticity on food commodities in 2018 in Tulungagung District obtained values of rice (-1.03) and corn (-1.17) where the price elasticity indicates that food commodities namely rice and corn are elastic because the elasticity value> 1. While commodity of green beans, peanuts, cassava and sweet potatoes obtained elasticity 
values of -0.42 each; $-0,75 ;-0.93$; and -0.77 where the price elasticity indicates that food commodities, such as mung beans, peanuts, cassava, and sweet potatoes, are inelastic because the elasticity is $<1$.

The resulting cross elasticity shows that most of the relationships between food commodities in
Tulungagung Regency have complementary relationships as indicated by a negative sign of the cross-elasticity value of the commodity. The results of the calculation of elasticity can be seen in table 3 (Marshallian elasticity), table 4 (Hicksian elasticity), and table 5 (expenditure elasticity).

Table 3. Marshallian Elasticity of Food Commodity Demand

\begin{tabular}{lllllll}
\hline \multirow{2}{*}{$\begin{array}{c}\text { Commodity } \\
\text { Prices }\end{array}$} & \multicolumn{7}{c}{ Food Commodity } \\
\cline { 2 - 7 } & Rice & Corn & $\begin{array}{c}\text { Green } \\
\text { bean }\end{array}$ & Peanuts & Cassava & $\begin{array}{c}\text { Sweet } \\
\text { potato }\end{array}$ \\
\hline Rice & $-1,03$ & $-0,15$ & 1,19 & $-0,13$ & $-0,12$ & 0,21 \\
Corn & 0,35 & $-1,17$ & $-0,50$ & $-0,14$ & $-0,17$ & $-0,11$ \\
Green bean & 0,28 & 0,13 & $-0,42$ & $-0,15$ & 0,12 & 0,02 \\
Peanuts & 0,25 & $-0,09$ & 0,05 & $-0,75$ & $-0,09$ & $-0,66$ \\
Cassava & 0,32 & $-0,07$ & $-0,59$ & $-0,007$ & $-0,93$ & 0,02 \\
Sweet potato & 0,28 & $-0,07$ & $-0,16$ & 0,04 & 0,02 & $-0,77$ \\
\hline
\end{tabular}

Source: Secondary Data Processed, 2019

The demand for food commodities can be seen from the calculation of price elasticity, cross elasticity, and income elasticity. Elasticity can show the response of households or consumers to changes that will affect consumer decisions such as price, income level, taste, etc.

In Table 3 that is marshallian elasticity, it can be seen that as many as 16 have negative cross elasticity, which shows that the related food commodities are generally parliamentary. The crossprice elasticity of rice that is negative is corn $(-0.15)$, peanuts $(-0.13)$, and cassava $(-0.12)$, which indicates a complementary relationship with other commodities. While the cross-elasticity value of rice that is positive is green beans (1.19) and sweet potatoes (0.21), which indicates a substitution relationship.

The cross-price elasticity of all corns is negative except rice $(0.35)$. Where the elasticity which is negative indicates a complementary relationship with other commodities if an increase in corn prices will be followed by a decrease in demand for the commodity green beans, peanuts, cassava, and sweet potatoes. The cross-marking elasticity of corn that is positive is rice (0.35), where if there is an increase in corn prices, the consumption of corn will be replaced by rice.

The cross-price elasticity of mung beans is all positive except for peanuts (-0.15). This shows that if there is an increase in the price of green beans, the consumption of green beans will be replaced by other commodities, namely rice, corn, cassava, and sweet potatoes. While the relationship between mung beans and peanuts is complementary with a negative sign of elasticity. The complementary relationship between mung beans and peanuts shows that if there is an increase in the price of green beans, it will be followed by a decrease in demand for peanuts.

The cross-price elasticity of peanuts that are negative is corn $(-0.09)$, cassava $(-0.09)$, and sweet potato $(0.66)$. Where the elasticity which is negative indicates a complementary relationship with other commodities if an increase in peanut prices will be followed by a decrease in demand for the commodity corn, cassava, and sweet potatoes. The cross elasticity of peanuts that is positive is rice (0.25) and mung beans (0.05), where if there is an increase in peanut prices, the consumption of peanuts will be replaced by rice and mung beans.

Cross-elasticity of cassava that is negative is corn (-0.07), green beans (-0.59), and peanuts ($0.007)$. Where the elasticity that is negative indicates a complementary relationship with other commodities if an increase in cassava prices will be followed by a decrease in demand for the commodity corn, green beans and peanuts. Crosselasticity of cassava which is positive is rice $(0.32)$ and sweet potato (0.02), where if there is an increase in the price of cassava, then cassava consumption will be replaced by rice and sweet potato.

The cross elasticity of sweet potato which is negative is corn $(-0.07)$ and green beans $(-0.16)$. Where the elasticity which is negative indicates a 
complementary relationship with other commodities if an increase in the price of sweet potatoes will be followed by a decrease in demand for the commodity corn and green beans. The cross elasticity of sweet potatoes that are positive is rice
(0.28), peanuts $(0.04)$, and cassava $(0.02)$, where if there is an increase in the price of sweet potatoes, sweet potato consumption will be replaced by rice, beans soil, and cassava.

Table 4. Hicksian Elasticity of Food Commodity Demand

\begin{tabular}{|c|c|c|c|c|c|c|}
\hline \multirow{2}{*}{$\begin{array}{c}\text { Commodity } \\
\text { Prices }\end{array}$} & \multicolumn{6}{|c|}{ Komoditi pangan } \\
\hline & Rice & Corn & Green bean & Peanuts & Cassava & $\begin{array}{l}\text { Sweet } \\
\text { potato }\end{array}$ \\
\hline Rice & 5,09 & 6,02 & 7,31 & 5,95 & 5,99 & 6,32 \\
\hline Corn & 2,22 & 1,02 & 1,67 & 2,00 & 2,00 & 2,06 \\
\hline Green bean & 0,05 & 0,24 & $-0,33$ & $-0,11$ & 0,18 & 0,08 \\
\hline Peanuts & 1,34 & 1,35 & 1,45 & 0,66 & 1,30 & 0,74 \\
\hline Cassava & $-0,42$ & $-0,40$ & $-1,04$ & $-0,48$ & $-1,35$ & $-0,43$ \\
\hline Sweet potato & 0,21 & 0,20 & 0,06 & 0,23 & 0,24 & $-0,52$ \\
\hline
\end{tabular}

Source: Secondary Data Processed, 2019

The result of hicksian elasticity calculation can be seen that the price elasticity of 2018 food commodities in Tulungagung Regency obtained values, namely rice (5.09), corn (1.02), and cassava $(-1.35)$ where the price elasticity indicates that the commodity food, namely rice, corn, and cassava are elastic because the elasticity value> 1 . While the commodity of green beans, peanuts, and sweet potatoes obtained elasticity values of -0.33 ; 0.66 ; and -0.52 where the price elasticity indicates that food commodities, such as mung beans, peanuts, and sweet potatoes, are inelastic because the elasticity value is $<1$.

In table 4 namely hicksian elasticity it can be seen that as many as 24 elasticities have positive cross elasticity, which shows that the related food commodities are generally substitution. The crossprice elasticity of rice is all positive, namely corn (6.02), green beans (7.31), peanuts (5.95), cassava (5.99), and sweet potatoes (6.32), where if an increase in rice prices, the consumption of rice will be replaced by corn, green beans, peanuts, cassava, and sweet potatoes.

The cross-price elasticity of corn was all positive, namely rice (2.22), green beans (1.67), peanuts (2.00), cassava (2.00), and sweet potatoes (2.06), where if an increase in corn prices, the consumption of corn will be replaced by rice, green beans, peanuts, cassava and sweet potatoes.

The cross-price elasticity of mung beans is all positive except for peanuts, which is -0.11 . Where the elasticity which is positive indicates substitution relationship, if there is an increase in the price of green beans, the consumption of green beans will be replaced by rice, corn, cassava, and sweet potatoes.
The cross elasticity of green beans which is negative is that of peanuts $(-0.11)$. Where the elasticity which is negative indicates a complementary relationship with other commodities if an increase in the price of mung beans will be followed by a decrease in demand for peanut commodities.

The cross elasticity of peanut prices are all positive, namely rice (1.34), corn (1.35), green beans (1.45), cassava (1.30), and sweet potato (0.74), where if an increase in the price of peanuts, then consumption of peanuts will be replaced by rice, corn, green beans, cassava, and sweet potatoes.

The cross-price elasticity of cassava is all negative, namely rice $(-0.42)$, corn $(-0.40)$, green beans $(-1.04)$, peanuts $(-0.48)$, and sweet potatoes $(-$ $0,43)$. Where the elasticity which is negative indicates a complementary relationship with other commodities if an increase in cassava prices will be followed by a decrease in demand for the commodity of rice, corn, green beans, peanuts, and sweet potatoes.

The cross elasticity of sweet potato prices are all positive, namely rice $(0.21)$, corn $(0.20)$, green beans (0.06), peanuts $(0.23)$, and cassava $(0.24)$ so they indicate the presence of substitution relationship. Where if there is an increase in the price of sweet potatoes, consumption of sweet potatoes will be replaced by rice, corn, green beans, peanuts, and cassava.

The Hicksian elasticity calculation results above show that all commodities tend to have a positive value of elasticity, so they have elastic elasticity. The positive sign indicates a substitution relationship so that the substitution effect occurs in the hicksian elasticity, but the marshallian elasticity 
indicates that the elasticity value tends to have a negative sign so that it has a complementary relationship and in the marshallian elasticity there is a substitution effect and income effect. The substitution effect is reinforced by the income effect (Nicholson, 1995). So that the non-price effect has a greater impact on consumer preferences.

Table 5. Elasticity of Expenditures Demand for Food Commodity

\begin{tabular}{|c|c|c|c|c|c|c|}
\hline & \multicolumn{6}{|c|}{ Food commodity } \\
\hline & Rice & Corn & Green bean & Peanuts & Cassava & Sweet potato \\
\hline $\begin{array}{c}\text { Expenditure } \\
\text { elasticity }\end{array}$ & 0,95 & 1,02 & 0,80 & 0,96 & 1,04 & 0,92 \\
\hline
\end{tabular}

Source: Secondary Data Processed, 2019

The value of the expenditure elasticity of food commodities in Tulungagung Regency shows that all of them have positive values. This means that if the consumer's income increases, the consumer will spend a small portion of the total demand for basic needs (food). This is in accordance with the law of engel which states that low-income households will spend most of their income to buy basic necessities (food). Conversely, high-income households will only spend a small part of the total demand for basic needs (food) (Nicholson, 2001).

The

value of the expenditure elasticity of food commodities in Tulungagung Regency shows that these commodities are normal goods because income rises followed by increased demand. The highest value of expenditure elasticity is in the commodity of cassava at 1.04 where the value is greater than one, which means that the increase in cassava consumption is greater than the revenue increase. While the lowest expenditure elasticity on green bean commodities is 0.80 and has a value smaller than one so it is not responsive to changes in prices of other commodities.

The Hicksian elasticity calculation results above show that all commodities tend to have a positive value of elasticity so they have elastic elasticity. The positive sign indicates a substitution relationship so that the substitution effect occurs in the hicksian elasticity, but the marshallian elasticity indicates that the elasticity value tends to have a negative sign so that it has a complementary relationship and in the marshallian elasticity there is a substitution effect and income effect. The substitution effect is reinforced by the income effect (Nicholson, 1995). So that the non-price effect has a greater impact on consumer preferences.

\section{Policy Implication}

Policy implication that can be taken from this research are pricing policies so as not to harm farmers or consumers so that the prices of these food commodities can be protected. In addition, it can also be formulated regarding food policy in the field of supply, distribution, and affordable prices in order to meet the food needs of the population and also can be carried out a program of assistance to improve the welfare of the population, especially residents with low income / poor nutritional status. So that the food surplus that occurs in Tulungagung Regency can be maintained.

\section{CONCLUSION}

Factors that influence the demand for food commodities in Tulungagung Regency are rice prices, corn prices, soybean prices, mungbean prices, peanut prices, cassava prices, sweet potato prices, and total household expenditure.

The elasticity of demand for food commodities in Tulungagung Regency consists of elastic marshallian price elasticities, namely rice and corn commodities, while those that are inelastic are green beans, peanuts, cassava, and sweet potatoes. In the elasticity of hicksian prices, elasticity is obtained, namely rice, corn and cassava, while those that are inelastic are green beans, peanuts, and sweet potatoes.

Marshallian cross elasticity indicates complementary relations and substitutions. Meanwhile hicksian cross elasticity has a substitution relationship between food commodities in Tulungagung Regency.

The expenditure elasticity of food commodities in Tulungagung Regency all have a positive value so that it shows that the food commodity is a normal item so that the price increase on food commodities will affect consumption expenditure from the people's income. 


\section{Suggestion}

For the government to provide policies that are not detrimental to farmers and consumers, namely the price policy. So that the price of food commodities can still be protected, and food policy can be formulated in the field of supply, distribution and price levels that are affordable and can meet the food needs of the population. For food aid programs to improve welfare, especially for low-income or malnourished residents.

For further research, it can conduct research on demand using the AIDS (Almost Ideal Demand System) model for a wider variety of commodities and can be used as a reference for future research.

\section{REFERENCES}

Anindita, Nur Baladina. (2017). Pemasaran Produk Pertanian. Yogyakarta: Penerbit ANDI.

Anindita, Ratya dan R. Reed, Michael. (2008). Bisnis dan Perdagangan Internasional .Andi: Yogyakarta.

BAPPENAS. (2011). Rencana Aksi Nasional Pangan dan Gizi 2011-2015. Badan Perencanaan Pembangunan Nasional (BAPPENAS). Jakarta: 10.
Nicholson,W. (1995). Mikroekonomi Intermediate dan Aplikasinya. Edisi kelima. Binarupa Aksara: Jakarta.

Nicholson, W. (2001). Mikroekonomi Intermediate dan Aplikasinya. Edisi kedelapan, Penerbit Erlangga. Jakarta.

Pusat Data dan Sistem Informasi Pertanian (Pusdatin). (2016). Outlook Komoditas Pertanian Sub Sektor Tanaman Pangan. Kementrian Pertanian. 56p. 